\title{
COCORI: UN NARRADOR FUERTEMENTE \\ REPRESENTADO Y UNA COMUNIDAD \\ DE NARRATARIOS INFANTILES
}

Maria Pérez Yglesias

\section{El narratario y la literatura infantil:}

Una de las conclusiones fundamentales a que se llega, después de un cuidadoso análisis de la crítica a la llamada literatura infantil (1), es que toda ella parte de la concepción del destinatario o narratario (2) niño. Es el narratario quien configura el discurso $y$, en última instancia, el género. El nombre mismo que se da al rubro: literatura infantil (o juvenil), o literatura para niños, hace referencia al lector virtual del texto. Se discute, en primera instancia, si este tipo de literatura es la escrita por niños para niños, o por adultos para niños (3).

De cualquier manera, siempre se exige tomar en cuenta, las características del posible receptor: la etapa sicológica en que se encuentra (animista, maravillosa, racional...) (4); el tipo de léxico y construcción que es capaz de asimilar; aquello que le pueda producir deleite, placer, $y$, desde luego, los valores morales y el aprendizaje que es importante transmitirle (5). La crítica plantea una estrecha relación entre este tipo de discurso y el folklor (6): ambas son producciones de "formación", en un caso, de la colectividad, en el otro, del individuo. Fábula y cuento infantil entroncan en el encuentro con lo maravilloso: se relaciona lo pequeño y lo normal con lo positivo, lo gigantesco con lo negativo; se personifican los animales y las plantas; se altera el espacio y se liga, básicamente, al movimiento; se da la ácronologicidad y la relación causa efecto se pierde; se presentan los procesos de "mejoramiento" y "degradación" de acuerdo con las condiciones de los actantes y el esfuerzo que estos hagan por obtener el triunfo del bien sobre el mal (7); se tiende al final feliz y al premio o al castigo justo (8). Los mejores estudios en este campo, los ha realizado Bruno Bettelheim (9), quien plantea la relación originaria del cuento de hadas con la representación de los procesos sicológicos del niño. Este encuentro positivo, entre lo maravilloso de los cuentos de hadas (10) y el niño, ha sido polémico: ya José Martí defiende la tesis del realismo de la literatura hecha para los niños, realismo que les permite -según él- una mejor adaptación al mundo que los rodea y un mejor desarrollo como ente social. Otros, sostienen una posición intermedia: ni un mundo maravilloso, puro que aleje lo circundante e impida la adaptación del individuo, ni un discurso que reproduzca fielmente la realidad sin permitir la fantasía y la creación (11). En síntesis, se puede afirmar que, la especificidad de la literatura infantil, se da en torno al consumidor y no al discurso mismo.

\section{El narratario en Cocorí:}

Joaquín Gutiérrez Mangel es autor de un solo libro para niños. La frase mi "hijo menor", con que califica afectuosamente a Cocorí (12), hace referencia, no a su última obra - puesto que Cocorí fue escrita en 1947 y tiene muchas más-, sino al hecho de estar dirigida a los pequeños, al hecho de ser literatura infantil.

Engendrada en la relación "padre cuenta-cuentos", Cocorí sólo se convierte en un discurso escrito, cuando ya ha sido "probado frente a los niños" (13), corregido y matizado por éstos. Es pues, un relato a la vez producto de la imaginación de un adulto que se implica al recordar aventuras de infancia (14) y de los niños que, como escuchas, preguntan, enfatizan, comentan o rechazan la historia: es literatura de recuerdos adultos de infancia, literatura de niños y para los niños. Además, la instancia de la enunciación presenta un enunciado, una historia, en que el protagonista es un niño de siete años, al que acompaña -en su búsqueda de conocimiento práctico (la selva y sus peligros) y filosófico (más vale vivir poco y ser útil que vegetar muchos años)-- la centenaria doña Modorra y, el también infantil monito Títí (15).

Es, Cocorí, el narratario interno más importante de la historia. El aprende de los otros, escucha las historias del Viejo Pescador, las reflexiones del Negro Cantor o los consejos de la Tortuga, quienes se convierten en narradores internos. En muchos momentos de la diégesis, se plantea lo que se puede llamar una comunidad de narratarios: un narratario interno representado por el Negrito ( $y$ a veces otros personajes) y el o los narratarios externos (16), quienes escuchan, aprenden y participan de la historia al mismo tiempo; en otras palabras, se establece una correlación o correspondencia en- 
tre ambos. Así, al caracterizar un tipo de narratario indirectamente se está caracterizando al otro.

\section{Las marcas del narrador}

Cocorí, como la mayoría de los relatos clásicos, es una narración ulterior a la historia. Se usa el pretérito pero no se especifica cuándo -ni dóndeocurrieron los hechos. El Negro Cantor, sin embargo, es capaz de adelantar el futuro y en algunas escenas, se utiliza el presente para aumentar la emoción y acercar al narratario virtual, a la acción; de todas formas el diálogo -la representación más mimética de la palabra - da ilusión de presente, aumenta la verosimilitud, el dramatismo $\mathrm{y}$, desde luego, constituye una apelación más directa al narratario.

En Cocorí, por su misma característica de literatura infantil, el narrador está fuertemente representado, además presenta dos niveles (17): el narrador del relato principal cumple una función ordenadora y cuenta la historia desde fuera, los otros narradores (internos) introducen los metarrelatos. En el texto aparecen varios relatos subordinados (metarrelatos) breves que no afectan, fundamentalmente, el relato principal, es decir, que podrían eliminarse sin afectar la coherencia de los acontecimientos. Son metarrelatos de carácter explicativo cuya función es la de enseñar, disminuir la curiosidad o simplemente informar al narratario que está dentro de la historia y a los que están fuera de ella (18).

\begin{abstract}
"Los correos de la selva nos contaron que los tres andan en busca de don Torcuato. Cuando conversaban en la playa, los escuchó el Moscardón; corrió a contárselo a su compinche el Tábano; éste se lo susurró al Yigüirro, que es compadre del Topo, el que tenía que hacer un manda. do por estos barrios y viajó toda la noche con la nueva" (64).
\end{abstract}

\footnotetext{
"No son cuernos de Talamanca. Es que ayer se comió un toro a la hora de la merienda. Se lo tragó de un solo bocado $y$, como los cuernos no le cupieron en la boca, le quedaron de fuera" (90).
}

Unos pocos relatos secundarios brindan información sobre las características personales del narrador que los asume, de su función dentro de la historia o de alguna acción específica ya pasada. Es, por ejemplo, la descripción que el gallo hace de sí mismo y de su labor matutina:

\footnotetext{
"-Yo tengo un clarín de oro y un gorrito carmesí y con mi canto sonoro despierto al caimán, al toro, al león, al jabalí, a la tortuga y al loro y al negrito Cocori"' (25).
}

Es interesante que, en el discurso, no se hagan referencias directas al acto mismo de narrar, una de las maneras que tiene el sujeto de la enunciación para mostrar que se trata de un trabajo de producción (19); el relato aparece, pues, como un enunciado donde se han borrado las huellas explícitas de la enunciación. Las huellas de la escritura son casi nulas, pero el narrador intenta establecer una comunicación afectiva e ideológica directa con el narratario (externo o interno). Esta comunicación del narrador (principal o de metarrelato) se dirige a la comunidad de narratarios y los configura de manera especial.

La situación narrativa, donde los protagonistas son el narratario (presente, ausente o virtual) y el narrador, configura -según G. Gennete- varias funciones: comunicativa, testimonial e ideológica. La primera de ellas, es decir la función de comunicación, se orienta hacia el narratario como "una preocupación de establecer o mantener con él algún contacto, un diálogo (real o ficticio)" (20). Esta relación explícita une, a la vez, la función fática (verificar el contacto) y la función conativa (influir sobre el destinatario) de Jakobson (21).

Las otras dos funciones - testimonial e ideológica- reflejan la orientación del narrador hacia él mismo y se relacionan con la llamada, por Jacobson, función emotiva o expresiva. El narrador asume una posición frente a la historia y tiene una manera específica de relacionarse con ella; esta relación puede ser afectiva, pero también moral o intelectual (22).

La función ideológica que puede ser reforzada o compartida por los personajes "manifiesta, explícitamente, el código ético del narrador y organiza los elementos del universo diegético, hacia la consecución de los valores expuestos" (23). Los actantes que se ajustan a dicho código serán positivos para el narrador y premiados con justicia, los otros, recibirán el castigo proporcional a su desvío dentro de la axiología propuesta. La función ideológica -que engloba gran parte de la comunicativa y la testimonial o expresiva - es, en este tipo de literatura, fundamentalmente didáctica.

\subsection{Rasgos explícitos de la comunicación:}

$\mathrm{Si}$, como se ha afirmado, el discurso infantil se construye tomando en cuenta, fundamentalmente, las características del destinatario-niño, la función de comunicación (contacto-influencia) alcanza, junto con la función ideológica del narrador, un lugar fundamental. 
Las formas que el narrador utiliza para establecer el contacto son variadas y se utilizan con propósitos diversos, veánse algunas de ellas:

3.1.1 El narrador hace suposiciones sobre los hechos, como si no los conociera, o brinda una información parcial: esto contribuye a mantener en suspenso al narratario:

"Pero un ruido lejano que crecía por momentos les pareció familiar. ¿Qué sería aquello?" (80).

"Pero don Torcuato no se divisaba. Debía estar tomando su baño matinal" (65).

Otras veces también se restringe la información y el narrador, perdiendo la omnisciencia, se pone a la altura de su receptor e "ignora" parte de lo que ocurrió:

"La pobre Tortuga se había caído de espaldas y patableaba que era un gusto en sus afanes por enderezarse. iQuién sabe cuánto rato llevaría en aquella posición!" (26).

En los dos primeros ejemplos, el narrador da a continuación los datos que por un momento dejó en suspenso; en el último, la omisión sirve únicamente para reducir al narrador al plano de desconocimiento del destinatario, y con ello lograr una mayor cercanía.

3.1.2. La familiaridad con que el narrador trata a los personajes lo acerca a ellos y al destinatario: para hacer a los viajeros "sus" amigos el narrador no utiliza el singular (mis), sino el plural (nuestros), y al hacerlo incluye también, al narratario virtual, dentro de la historia.

"Era oscura la selva por donde caminaban nuestros amigos" (58).

"La selva continuó abriéndose ante nuestros tres amigos" (79).

3.1.3 En ocasiones, el narrador da pistas al narratario, adelantando, en cierto sentido, lo que va a suceder después. Por ejemplo, primero asegura que no escasearon las aventuras, y luego empieza a contarlas; o informa de antemano cómo la mañana resultó estéril por culpa del monito, e inmediatamente refiere todas sus travesuras:

"Aunque no escasearon las aventuras. En la tarde descubrieron un panal de miel..." (80).
"Al día siguiente perdieron toda la mañana por culpa del Títi. Alegre con la idea del regreso..." (100).

3.1.4. Así como algunas veces, el narrador restringe la información que posee y se sitúa a la altura del narratario, en muchas otras, hace lo contrario: repite, interpreta y traduce la información, configurando un tipo de destinatario que necesita aclaraciones:

\subsubsection{Interpreta los gestos de los personajes:}

"Lo de filósofa se lo ganaba con su cara de ausente siempre como rumiando pensamientos muy profundos" (28).

"...dijo la Tortuga con una sonrisa torcida, como diciendo: ¿Qué pueden saber esos recién nacidos?" (51).

“...agregó jadeando la Tortuga, porque nunca había pronunciado un discurso más largo en su vida” (52).

Como puede observarse, en las citas anteriores, se da una explicación a la sonrisa torcida, a la cara de ausente o al jadeo de la Tortuga; el narrador dice lo que podría suponer el narratario.

3.1.4.2. Traduce las onomatopeyas: cada una de las emisiones de los personajes zoomorfos es inmediatamente transcrita al lenguaje humano:

"Cri, cri, cri

apúrate, Cocorr" (12)

"Estucurú,

¿qué buscas tú?"'(12)

"Quiquiriquí,

ya estoy aquî" (15)

"Croá, croá,

ya las pagará" (36).

3.1.4.3 Utiliza la onomatopeya de ruidos y sonidos para resaltar un hecho:

"En la tierra reseca, sin la alfombra de verdura, las pisadas repercutían en el silencio impresionante:

$-T o c, t o c$, toc.

Al Tití ya no le parecía suficiente el conjuro" (87)

"Cocorí le tocó con los nudillos la espalda:

- iTun, tun!

Pero ya la otra estaba en el quinto sueño" (94)

El ruido producido por las pisadas o por los golpes, puede eliminarse sin que se oscurezca la diégesis. Estas onomatopeyas le sirven al narrador para reafirmar la acción que las produce, y con ello lograr una mayor verosimilitud. 
3.1.4.4. Hace énfasis sobre algo que ya se ha narrado o que se sobreentiende:

"El tronco se remeció. Y junto al ojo del Tití se descorrió una costra rugosa. En el fondo había un ojo inyectado en sangre que lo miraba echando fuego. iEl tronco del árbol era el Caimán!'”(65).

"Cuando Cocorí, .... ..., pasó por allí, lo oyó, todo importante, exagerando sus aventuras en la selva.

... entonces le mordí la cola a Talamanca...

Claro que el Tití se guardaba bien de decir que Talamanca estaba dormida" (104).

3.1.5 Se apela a un narratario con características definidas cuando se le aconseja, enseña o asevera; cuando se le informa sobre aquello que el narrador considera que tiene importancia o interés.

El que narra, emite una serie de aseveraciones, de afirmaciones contundentes sobre el universo de la diégesis, dirigidas a la casi obligada aceptación por parte de quien las recibe:

“El Tití, empecinado en su cacería, metió la cabeza por la estrecha abertura. iBuen castigo sufrió su testarudez!'"(100).

"Consiguió aplacar al hombre, salvando al mono de su cólera tan justa" (34).

Otras veces se pretende mostrar dónde está el peligro, o enseñar reglas de educación:

“...saltando entre las rocas con riesgo de resbalar y darse un peligroso chapuzón” (18).

"Y por asociación de ideas bostezó tanto que casi se zafa la quijada, lo que era insólito en una tortuga tan bien educada"' (39)'

Pero el interés de la función comunicativa se centra, básicamente, en las distintas informaciones que, se brindan a través del peregrinaje de los tres amigos (Cocorí, doña Modorra y el Tití), en busca de una respuesta. La situación que se presenta, cuando se incursiona por una selva casi desconocida, le sirve al narrador para explicar aquellas cosas prácticas que puedan interesar al narratario: cómo la mejor agua es la recogida por los cálices de las flores, cómo el mal olor provocado por un zorrillo hediondo se puede eliminar con plantas del bosque, cómo para descansar es fácil construir una cama con elementos naturales...

\footnotetext{
"Regresaron y con gran pericia se puso a construir una cama. Plantó las cuatro horquetas, atravesó varios palos encima, lo amarró todo con bejucos y lo cubrió con anchas hojas de plátano" (59).
}

"Le dieron fricciones de orégano, perejil, albahaca y todas las yerbas olorosas que pudieron encontrar. iLlegaron al recurso final de fregarlo con floripondio y por fin lograron dejarlo totalmente inodoro!" (101).

Paso a paso, el narrador explica aquello que contribuye a aplacar la curiosidad del destinatario, o enseña acerca de los animales y sus acciones en ese ambiente tropical: menciona árboles, flores y frutos existentes; comenta sobre la vida y edad de las tortugas, la agilidad, rapidez y fogosidad de los monos; informa cómo las serpientes cazan a los pajarillos; cuenta cuál es la relación entre los plumones y los lagartos,... Es común que los personajes, a su vez, traten estos temas, reforzando la función didáctica del narrador:

“... agradecí6/don Torcuato/ infinitamente el papel de palillo de dientes que cumplía su amigo /el Plumón/a la perfección" (66).

"Los pájaros, ante esa mirada hipnotizante, sienten que las alas se les paralizan y comienzan a acercarse como sonámbulos. La culebra no hace otra cosa que mirarlos, vibrando su lengua viperina entre las fauces. EI pájaro salta de rama en rama, siempre acercándose, sin poder apartar la vista, hasta que se va de bruces en la bocaza abierta" (81).

Después de analizar la función comunicativa del narrador primero hacia el narratario virtual, es fundamental referirse al narratario interno (individual o colectivo).

El destinatario diegético interno de mayor importancia -ya se ha dicho- es el protagonista; a él se dirigen (cuando está solo o acompañado) todas las referencias de los otros personajes. Las informaciones de los narradores-personajes pretenden explicar aquello que produce curiosidad, que puede significar peligro, que se debe saber, etc.:

"-Por lo mismo, mocoso imprudente. i-No comprendes que si los pájaros han respetado esas tan tentadoras es porque deben ser venenosas?" (60).

"Tienes que ser muy educado, Cocorí; ya sabes que don Torcuato es muy quisquilloso. Trata de halagarlo, porque es muy sensible a las adulaciones. Es triste esto... ...que tengamos que recurrir a armas innobles, pero no hay otras" (58).

De los fragmentos anteriormente transcritos se infieren varios aspectos importantes: sin excepción dentro del "corpus", las instancias narrativas segundas responden a preguntas hechas por Cocorí. Los que le rodean tratan de ser su guía y educarlo, de contestar sus preguntas, de aliviar sus pesares $y$ 
de darle protección para que nada le suceda. El personaje que cumple esta misión didáctica es casi siempre doña Modorra, pero se presentan los casos del Viejo Pescador y el Plumón.

La comunidad de narratarios explícita, se intenta en algunos casos; por ejemplo, cuando doña Modorra enseña el conjuro, la apelación al aprendizaje va más allá de Cocorí. No se contenta con el plural "vamos a aprenderlo" y agrega un todos que sugiere, aún más, la idea de colectividad. En el capítulo VII, el Negro Cantor recita a mamá Drusila el conjuro:

"La culebra lo quiere comer,

Talamanca, la Bocaracá

iCrótalo, que no lo comas,

y la culebra se va!" (77).

En este momento, la referencia que hace es personal: "no lo comas". Luego, antes de enseñar Modorra la fórmula mágica, dice:

"Vamos a aprenderlo todos y lo diremos con gran fervor. Hay que poner el alma al decirlo para que surta efecto" (82).

Más adelante se repite el conjuro completo, pero cambia el pronombre:

"-La culebra me quiere comer,

Talamanca, la Bocaracá.

iCrótalo, que no me coma.

y la culebra se va!" (83)

El hecho de que, a pesar de querer que se aprenda en conjunto, se cambiara la partícula lo por me, indica que cada uno de los individuos debe protegerse a sí mismo, pero no limita, como en el primer caso, a una sola persona; abre la posibilidad de un narratario colectivo.

A través de los distintos narradores internos en Cocorí se logra una excelente configuración del narratario; como el narrador del relato principal brinda a su destinatario externo las mismas informaciones (a nivel de función comunicativa), y le da un trato similar, puede afirmarse que ambos receptores son semejantes: en el primer caso un niño de 7 años, Cocorí; en el segundo, un público, un público infantil.

\subsection{La función ideológica-didáctica:}

La función ideológica en este relato se da (tanto la del narrador como la de los personajes) en dife- rentes niveles. Se pueden hacer gradaciones con base en los extremos "concresión-abstracción" situando, los comentarios de orden práctico (parte de la función comunicativa) entre lo más concreto; luego, los refranes implícitos, las máximas morales, el código de valores del narrador (confirmado por la expresividad del narrador); y por último, el plano filosófico como lo más abstracto (24).

Las funciones comunicativa e ideológica están estrechamente relacionadas. Se puede afirmar que la ideología subordina parte de la función comunicativa. Se trata de transmitir, a través de consejos prácticos, de enseñanzas didácticas, una visión de mundo concreta, dirigida a un narratario de cierta capacidad receptiva; el narrador muestra simpatía o antipatía por los personajes, según sus rasgos morales y las acciones que realizan.

A menudo se da una conjunción de lo bello-bueno-pequeño, y de lo feo-grande-malo; se justifica la belleza por los valores espirituales y la fealdad por la carencia de éstos. Existe también una función ideológica propiamente dicha que el narrador comparte con los personajes: el por qué de la fugacidad de lo positivo, conduce toda la aventura que finaliza con el premio a la perseverancia y decisión del protagonista: la respuesta. Se plantea en ella toda una filosofía de la existencia: se puede vivir mucho, en poco tiempo, si se vive haciendo el bien, o vivir poco, en largas décadas, si solo se vegeta.

En el análisis posterior se ha procurado un orden: se parte de las ideas concretas, hasta llegar a la máxima abstracción. El estudio se iniciará relacionando las funciones comunicativas e ideológicas y lo que ello implica; después se sacará un código de valores general, y, por último, se tratará de establecer la visión de mundo, la ideología que comparte el narrador con algunos de sus personajes positivos.

3.2.1. En la función comunicativa (apelación o acercamiento al narratario) se empieza a fundamentar lo ideológico; tanto el narrador principal como los internos enseñan a sus narratarios lo que se puede hacer y cómo hacerlo.

-El narrador aconseja, informa o asevera para lograr algún objetivo en su destinatario: comenta las acciones (es peligroso saltar de roca en roca recogiendo caracoles, es de maleducados bostezar con la boca abierta); explica algunas relaciones entre elementos de la naturaleza (existen aves, los plumones, que se alimentan con las fibras de rana que quedan en los dientes de los lagartos; las cule- 
bras ejercen un poder hipnótico sobre los pájaros y los atraen para comérselos); o da conocimientos prácticos a los viajeros (cómo hacer una cama o de dónde tomar el agua; no se debe meter la mano en' cualquier agujero, ni sentarse en el suelo sin fijarse antes...)

- Los personajes también enseñan, advierten, aconsejan:

"Tienes que ser muy educado, Cocorí, ya sabes que don Torcuato es muy quisquilloso. Trata de halagarlo porque es sensible a las adulaciones. Es triste que tengamos que recurrir a armas innobles, pero no hay otras" (58).

Este ejemplo tiene gran interés; es la única ocasión en el "corpus" en que se pide a un personaje realizar una acción que rompe el código de valores establecido, por eso la Tortuga trata de justificar el hecho.

Cuando realizan la incursión por el bosque, doña Modorra protege a sus amigos no dejándoles comer unos frutos que se muestran apetitosos y les explica la razón:

"¿No comprendes que si los pájaros han respetado esas tan tentadoras es porque deben ser venenosas?" (60).

A la pregunta de Cocorí sobre el por qué, en tierra de serpientes, no se aventuran los pájaros, su consejera responde:

"Porque la culebra los mira fijamente con sus ojos de vidrio acuoso y los comienza a traer" (81).

"Por eso, por si acaso... ..., lo mejor es no mirarles de frente" (82).

Más tarde, ella misma dice qué son los cilindros transparentes y calcáreos que se encuentran en la zona donde habita Talamanca y cómo la digestión de uno de estos ofidios puede durar largo tiempo:

"-No te asustes tanto; es la piel que las víboras mudan dos veces al año..." (83).

“-Pero esas siestas duran semanas" (93).

Cocorí interroga al Viejo Pescador acerca de quién es más fuerte, la Serpiente o el Caimán, y éste le responde:

"Si el Caimán la muerde primero, gana el Caimán, pero si la Serpiente lo aprisiona en sus anillos y comienza a destrozarlo con su abrazo, iAdiós Caimán!" (14).

Más adelante, cuando el Negrito, atolondrado, ofende a don Torcuato y éste trata de atraparlo, doña Modorra brinda su consejo salvador:

“- iCocorí, no corras en línea recta, porque te alcanza! iCorre haciéndo círculos!" (72).

En este ejemplo, como en muchos otros, el narrador refuerza lo dicho por el personaje:

"-... porque si en las rectas corre como un caballo al galope, en cambio para darse vuelta le estorban su enorme armazón y sus vértebras torpes" (73).

El narrador, además de manifestar directamente su apoyo a las ideas o enseñanzas de los actantes, utiliza otro recurso que por su carácter ambiguo resulta apropiado: el discurso transpuesto indirecto libre:

"Las tortugas nunca tienen espíritu de aventura. Cerca de la playa está el recurso de lanzarse al mar y escapar de los enemigos, pero en mitad de la selva..." (55).

"Aferrado a sus faldas se sintió tranquilo, porque las mamás pueden defender a sus negritos de la montaña, del hambre, del jaguar y del relámpago"' (13).

En el primer caso, se enseña algo acerca de las tortugas, en el segundo se muestra la seguridad que significa una madre para los niños. Aquí, el personaje y el narrador comparten la comunicación; no se sabe a ciencia cierta à quién pertenecen las palabras.

En aquellas ocasiones en que el narrador y los personajes comparten sus ideas, $y$ en el discurso indirecto libre, la ironía se constituye en un recurso valioso para hacer énfasis en aspectos ideológicos:

"Don Lagarto pensó para sus adentros lo bien que le vendría un poco de propaganda para convencer a algunos escépticos que no le reconocían sus méritos" (67).

“ $i-Y$ qué te has figurado? -Doña Modorra se pavoneó coqueta- Si tengo solo ciento cincuenta años, lo que no es nada para nosotras, que vivimos trescientos...-Cocorí, un poco desconfiado, le miró las 'patas de gallo' y los centenares de arrugas del pescuezo,..." (27).

Se ironiza acerca del poder de la propaganda y las pretensiones juveniles de doña Modorra, en ambos casos la burla se establece referencialmente.

Implícitamente, algunas enseñanzas implican una máxima moral o un refrán popular:

En la contestación del Viejo Pescador y en la orden que doña Modorra da a Cocorí cuando huye de su enemigo, se trata de demostrar que "más vale maña, que fuerza". En el primer caso la Culebra y 
el Caimán son poderosos, pero vencerá aquel que logre atacar primero; en el segundo, solo la astucia puede salvar al débil de su feroz contrincante.

En la conversación acerca de los frutos del bosque, se muestra cómo "las apariencias engañan"; no todo lo que se ve positivo por fuera, lo es también en su interior.

Cuando Talamanca reposa dormida y el protagonista la observa, piensa de ella:

"Una persona con un vientre tan majestuoso y un sueño $\tan$ satisfecho, tiene que ser alguien muy importante" (94).

A pesar de la referencia irónica, se demuestra, una vez más, que no siempre lo que parece, es. Pero no sólo lo que se ve puede resultar falso, es factible partir de ideas preconcebidas o expresadas por otros, que no responden a la realidad: Cocorí cree que los adultos deben conocer la verdad y por eso se desilusiona cada vez que no pueden contestarle; por su parte, doña Modorra:

“... había quedado muy escéptica acerca de la sabiduría de los grandes y algunos prestigios impuestos que reinaban en el bosque" (96).

Algunas veces se explicitan máximas morales. Cuando Cocorí pide consejo a doña Modorra para atrapar al Tití prometido, ésta le dice:

"Explota sus vicios, Cocorí y lo atraparás: Siempre los vicios acaban por perder al débil que no sabe dominarlos" (28).

Como puede observarse, la premisa es bastante amplia (vicios en general), sin embargo en el relato se particulariza; se hace referencia, básicamente, a la gula, y con ella al goloso e icorregible Tití:

"-El Tití es goloso... .... La gula lo pierde" (28).

"-Se los va a llevar la trampa por golosos" (30).

"Cegado por la gula, no atinaba a soltar la golosina para escaparse..." (33).

Tití descubre un panal de miel y trata de robarse su contenido. Más tarde, todo aguijoneado por las abejas, se lanza de cabeza a una poza y la Tortuga comenta:

"Merecido se lo tiene, la codicia rompe el saco" (81).

El plumón casi muere en manos del goloso que, en otra ocasión, persigue una mariposa para comérsela y se mete en un tronco.
"Era esa la madriguera de un zorro hediondo que apestó de mal olor al pobre monito" (100).

Las informaciones, enseñanzas explícitas, refranes y máximas morales son a la vez apelaciones al narratario y portadoras de ideología. Como ya se afirmó, el narrador a través de la frase que refuerza, el traspuesto indirecto libre y la ironía, comparte en muchos casos, la ideología de los personajes positivos.

3.2.2. La función expresiva, como ya antes se dijo, se encuentra totalmente subordinada la ideológica: depende de las ideas y actuaciones de los personajes el que el narrador los califique como seres agradables o no. Para sacar el código de valores que sustenta la historia, se puede proceder, pues, a la inversa: se toma como punto de referencia la subjetividad narradora hacia los personajes y sus acciones (simpatía o antipatía) y, basándose en ella, se extraen aquellos valores que merecen aprobación o desaprobación, premio o castigo.

Casi nunca el narrador manifiesta de manera explícita su opinión favorable acerca de la conducta o carácter de un personaje.

A través de la manera de ser y actuar de Mamá Drusila y de doña Modorra se conoce su amor y preocupación maternal; esta virtud se exalta mediante la expresividad positiva:

"Tu mamá ha andado loca buscándote" (101).

"Usted que ha sido una segunda madre para mí, por lo que más quiera, ayúdeme" (55).

"De un abrazo alzó a Cocorí hasta quedar su carita junto a la suya. - iMi chiquitito: ¿dónde estabas, hijo mío? ¿Qué te habías hecho? - Y los besos llovían sobre el rostro del Negrito" (107).

Pero no sólo se exaltaban las cualidades de una madre; el amor filial y lo que éste conlleva es también fundamental: Cocorí siente respeto por las órdenes maternas y por eso no se atreve a contestarle "lleno de remordimientos porque siempre le había prohibido que se aventurara en el bosque" (13); casi al final de su aventura en la selva, cuando espera en los terrenos de Talamanca que su amiga despierte, recuerda: “...a mamá Drusila, que no sabía de él hacía tantos días; y las lágrimas le corrieron a raudales pensando en el tibio amor de la negra" (95).

"En el recuerdo le humeaba el tazón de leche caliente que le llevaba en las mañanas Mamá Drusila" (59). 
Mientras vive en el rancherío, la vida de Cocorí transcurre feliz, recibe los cuidados de su madre, aprende en el círculo de pescadores, y lo fundamental: cumple una función en su casa, ordeña las cabras, recoge leña y prende el fuego; colabora, aunque en algunas ocasiones olvida su responsabilidad. Existen, pues, valores de familia; una relación materno-filial positiva.

Otro conjunto de valores importantes, es el que se da en torno a las aventuras de la selva. El Tití es víctima de su gula, falta de previsión, espíritu travieso e irresponsable y se castiga su irreflexión, testarudez y cobardía. Cocorí está a punto de sufrir daños por su atolondramiento e imprudencia. Doña Modorra es blanco de la ironía del narrador por su coquetería, sus pretensiones juveniles, su superficial pose de filósofa, su lentitud perezosa y su espíritu timorato. De don Torcuato se rechaza el materialismo, la fuerza bruta, la gastronomía y sobre todo ese deseo de ser adulado y, Talamanca la Bocaracá, desagrada por su vida inútil, vegetativa y su carácter devastador y ruinoso.

Se puede concretar, pues, un denominador general: por un lado son negativas la irreflexión, la falta de madurez y de valores espirituales, el egocentrismo, el poco espíritu de servicio; por otro, se alaban la gratitud, la justicia, la decisión, la astucia, el conocimiento, la colaboración desinteresada y el cariño, la sensibilidad y la intuición.

La historia tiene un final feliz y el protagonista recibe su premio, porque busca la verdad venciendo el temor a la selva y a la noche, arriesgando la vida ante los "seres malignos", con entusiasmo y perseverancia.

3.2.3. El motor que mueve la diégesis es Cocorí; su problema, surge ante la idea de un barco y la muerte temprana de la Rosa que le regaló la niña rubia, que venía en él. A partir de ese momento, la preocupación del protagonista se plantea en dos niveles: uno concreto (deseo de prolongar la compañía de la rosa hasta su edad adulta), que se resuelve con la sorpresa del rosal plantado por Mamá Drusila; y el otro, abstracto, en el que el niño se pregunta por qué la rosa buena y bella vivió un día y los malos e inútiles cientos de años, y cuya solución la da el Negro Cantor al afirmar que "más vale un minuto útil que un año inútil". La función ideológica más importante se va a dar, pues, en torno a esas dos perspectivas.

Cuando el Negrito llega a su rancho y encuentra la flor marchita y deshojada, se lamenta de que hu- biera vivido sólo un día y entristece al pensar que no podría decir, como el Viejo Pescador:

\footnotetext{
"-Cuando yo tenía siete años esta Rosa nació. Me ha acompañado toda la vida" (45).
}

El narrador comparte con el personaje esta idea, y lo manifiesta explícitamente al final del relato:

"Cocorí podría decir más tarde con orgullo: -Yo tenía siete años cuando este rosal fue plantado" (107).

Se muestra aquí, la necesidad del protagonista de conservar aquellas cosas materiales que son importantes en la vida, de prolongar el recuerdo acompañado de la evidencia, de tener cosas que contar y mostrar. Hay un sentimiento de prolongación en la naturaleza.

Ese deseo de ser en las cosas, se evidencia en la preocupación por lo momentáneo, por lo fugaz.

El día que Cocorí se escapó al bosque por primera vez, descubrió su propia imagen en el agua tranquila de la poza, casi de inmediato palmoteó en el espejo natural y "su retrato se quebró en multitud de fragmentos" (11). La fugacidad de su propia imagen es significativa, es la brevedad de la vida que más tarde se comprobará en la Rosa y que contrapone a la longevidad de algunos personajes. A través de todo el relato se hace énfasis en la edad y experiencia de los actantes. Cocorí espera de ellos la contestación al absurdo de la vida:

"El mundo marcha de cabeza y yo soy un niño y no puedo comprenderlo" (45).

“¿Cómo podría esperar cien años en un mundo patas arriba?"' (52).

Primero busca la respuesta en el mundo de los adultos, y confía en que, el Viejo Pescador, lleno de canas y experiencia, podrá contestarle. Los hombres no pueden calmar su inquietud y la esperanza renace al ver a doña Modorra con sus decenas de años a cuestas:

“- iEsta sí que debe saber! iCon sus ciento cincuenta años de experiencia!" $(50)$.

Los otros animales del bosque, que a lo largo de la aventura se cree pueden contestar al niño, son aún más viejos:

"Don Torcuato, el más viejo de los caimanes. Era amigo de mi abuelo. Tal vez él pueda darte la respuesta" (52).

"-Es la más vieja de las serpientes - continuó el niño-, y nos podrá explicar por qué el mundo anda patas arriba" (74). 
Pero la respuesta no la da nunca la vida prolongada, ni lo que esta vida ha podido enseñar.

$\mathrm{Si}$ bien es cierto que la experiencia no es lo fundamental, no se puede negar su valor; todas las aseveraciones y aclaraciones del Viejo Pescador y, sobre todo las enseñanzas de doña Modorra existen gracias a su larga vida y a los conocimientos adquiridos en ella:

"Cocorí agradeció una vez más a la sabia Tortuga. ¿Qué habrían hecho sin su valiosa experiencia?"' (60).

La hermosura y la bondad son cualidades inherentes a la Rosa, lo mismo que su vida fugaz:

"Era tan hermosa, esparcía sólo bondad, y en un día se deshojó" (71).

"-Pero, por qué, Negro Cantor, si mi Rosa era linda y buena ¿por qué tuvo una vida tan corta?" (102).

Sin embargo, lo trascendente en ella es su capacidad de darse a los demás, de contagiar sus virtudes a quienes la circundan. Con su compañía Cocorí es feliz, considera agradable todo lo que le rodea y realiza acciones positivas como no lo hubiera hecho antes:

"Pero el recuerdo de la Rosa endulzaba su alma y nunca Cocorí se había sentido más bueno que aquella mañana" (27).

Desde el principio, a través del indirecto libre, se compara a la flor con los "añosos" del bosque:

\footnotetext{
"iQue su Rosa hubiera vivido un día y en cambio otros, que de nada servían sino para hacer el daño, vivieran tantísimos años!" (45).
}

"...sintió otra vez el fuego de la rebeldía. Que ese animalote maligno tuviera trescientos años y su Rosa sólo un día..." (67).

En este caso, los que viven cientos de años son "malignos", "no sirven para nada", "arrastran una existencia sin sentido". Aquí se da la clave del misterio: una vida corta pero bella y útil, y una larga, negativa y sin sentido.

En el "corpus" varios de los personajes tienen una filosofía de la vida bastante coherente. ElViejo Pescador y don Torcuato la explicitan en pocas palabras:

"-Cada pregunta que yo me hice me dejó una arruga en la frente. Cada misterio que quise comprender me dejó con un diente menos. Ahora tengo más arrugas que olas tiene el mar, y mira cómo me quedaron las encías-. Le mostró sus encías lisas y rosadas y terminó: -Ahora espero que el oceáno y el bosque me cuenten lo que me quieran contar. Yo no les pregunto nada"- (48-49).

“...: ¿Cómo podía nadie interesarse por una flor, algo tan insignificante? ¿Para qué servían las flores? ¡No se podían comer! Había que ser tan tonto como una mariposa para quererlas. El había esperado que le preguntaran algo respecto a sus gustos culinarios, a su última pelea con el Toro salvaje, o algún recuerdo de su padre, don Torcuato el Viejo, tan venerable que tenía el recuerdo de cuando llegaron las carabelas de Colón. ¿Pero una flor? ¡Puah!" (71).

Estos actantes son seres opuestos (uno de los más y otro de los menos simpáticos para el narrador) $y$, sin embargo, ninguna de las dos versiones del mundo que presentan es aprobada por el narrador. Este comparte la filosofía del Negro Cantor. Como se vio antes, a través del relato se cree que la edad y la experiencia son capaces de solucionar los problemas y se llega a la conclusión de que sólo en aquellas cosas cotidianas o de relativa importancia esto es así. A nivel de planteamiento existencial son otras las cualidades que se necesitan: sólo el Poeta, el hombre "sensible" e "intuitivo", el profeta Cantor posee la "verdad".

Desde el epígrafe, el narrador da la respuesta a la inquietud de Cocorí:

"A breve vida nace destinada. / Sus edades son horas en un día” (9).

Pero en la historia, es el Negro Cantor el que desentraña el enigma:

"-Pero por qué, Negro Cantor, si mi Rosa era linda y buena, ¿por qué tuvo una vida tan corta? - Te engañas Cocorí -sonrió el Cantor con un relámpago de dientes blancos-, no fue una vida corta. -Si ya te lo dije, vivió sólo un día. $Y$ ahí tienes a don Torcuato y a Talamanca hinchados de tiempo. El Cantor acomodó al Negrito sobre sus rodillas: - $i$ No viste que tu Rosa tuvo una linda vida? -le preguntó-. ¿No viste que cada minuto se daba entera hecha dulzura y perfume?

-Oh, sí, icómo me llenó de felicidad!

- ¿Qué es la vida de Talamanca la Bocaracá, que se arrastra perezosa asolando todo a su paso y durmiendo largas digestiones? ¿Y don Torcuato, bilioso por el poder de su vecina, que se desquita haciendo daño a su alrededor?

Cocorí se estremeció ante el recuerdo...

El Negro Cantor prosiguió:

-Tu Rosa vivió en algunas horas más que los centenares de años de Talamanca y don Torcuato. Porque cada minuto útil vale más que un año inútil.

Cocorí sentía que una luz lo empapaba por dentro.

Hay un detalle fundamental que se debe recalcar: siempre que doña Modorra y el Viejo Pescador responden a las dudas, enseñan o protegen a Coco- 
rí, las afirmaciones se hacen categóricas: son aseveraciones, advertencias, órdenes, sentencias o consejos. El Cantor no afirma, sino que pregunta y sugiere; de esta forma, conduce a la verdad.

Más adelante, Cocorí, lleno de emoción repite a mamá Drusila lo que al fin pudo comprender:

"Mi flor tuvo una vida muy larga; me lo explicó el Cantor. -Sí, ¿cómo?

-Dice que tuvo una vida apretada, que en un día vivió más que el Caimán y que Talamanca, porque pasó haciendo el bien" (107).

Las gratificaciones que recibe Cocorí por su conducta, como ya se manifestó, se dan en dos niveles: uno espiritual y uno concreto: la respuesta que le dio la poesía y el rosal que le brinda el amor cotidiano de Mamá Drusila:

"Con los desvelos de la Negra, que la había regado día y noche,... en el centro del jardín crecía un rosal” (107).

En síntesis, en relación con el narrador y el narratario se pueden entresacar algunos aspectos interesantes:

- La llamada literatura infantil o para niños, se define con base en "el lector virtual", narratario o consumidor del texto y no en relación con el discurso mismo. Por tanto la gran mayoría de los estudios que se conocen sobre ella son de carácter referencial y se basan en las características de ese destinatario posible.

-El relato Cocorí de J. Gutiérrez Mangel, es decir, un texto para niños escrito por un adulto que recuerda sus experiencias infantiles y somete su discurso a la crítica y corrección previa de otros niños - sus hijas-, presenta una comunidad de narratarios infantiles. La configuración que se hace de los narratarios internos, en especial de Cocorí, protagonista de siete años, permite deducir la caracterización de los narratarios externos (aquellos a quienes va dirigido el relato).

-El narrador - tanto el del relato principal como de aquellos relatos secundarios (metarrelatos)- está fuertemente representado, y utiliza muy diversas formas de establecer el contacto con el narratario: brinda informaciones parciales para mantener el suspenso; se sitúa en el mismo plano de los narratarios utilizando incluso el pronombre nosotros; informa sobre lo ocurrido y adelanta la diégesis; aclara, explica, repite o aconseja pero, sobre todo, asevera y enseña. Además de estas formas directas de comunicarse con los narratarios, utiliza otros recursos como el estilo traspuesto indirecto libre, la sabiduría popular (máximas, refranes, dichos) y la ironía, todos ellos donde se presenta cierta ambigüedad siempre resuel ta de manera unívoca.

-En cuanto a las funciones en relación con el narrador y con el narratario, en Cocorí tienen importancia diversa: la función ideológica y dentro de ella la didáctica es la más importante y engloba las funciones expresiva y parte de la comunicativa.

-En la historia, es el narratario Cocorí, quien plantea los problemas, induce a la explicación, la enseñanza y la reflexión de aquellos personajes que sostienen la función ideológico-didáctica: doña Modorra (didáctica, moralizante, cotidiana, concreta y llena de la experiencia que dan los años) y el Negro Cantor (inductivo, filósofo de la existencia, intuitivo, sensible, poeta). La experiencia y la vejez se valorizan ante lo cotidiano y lo concreto, pero si no se tienen otras cualidades, estas no sirven de mucho (es el caso de Don Torcuato y Doña Talamanca), la respuesta a lo existencial solo puede darla la sensibilidad, la poesía...

- La función ideológica es compartida por el narrador en sus distintos niveles y se manifiesta en una escala que va de lo más concreto (comentarios de orden práctico, cotidiano) pasando por los refranes y máximas implícitas y por un sistema de valores, hasta llegar al plano filosófico como lo más abstracto. El premio a la perseverancia e interés de Cocorí, lo que constituye el final feliz del texto y el eje que sostiene el relato, se da en los dos planos: un rosal regado con paciencia cotidiana, una respuesta al sentido de la vida útil. 


\section{REFERENCIAS BIBLIOGRAFICAS:}

(1) En la tesis de licenciatura, Rasgos comunes de tres categorías de análisis en el relato literario, presentada por Patricia Araujo, Sonia Jones, Ligia Bolaños y María Pérez Y. (Escuela de Filología, Lingü ística y Literatura, Universidad de Costa Rica, 1977) se hace un análisis de la crítica sobre literatura infantil de habla hispana. Confrontándose la introducción en las páginas 11-41.

(2) Resulta pertinente aclarar la terminología empleada en cuanto a los dos extremos de la comunicación: emisor/receptor, a los que R. Jakobson llama destinador/destinatario y que, colocados en la situación narrativa G. Genette nombra: narrador/narratario. El sujeto de la enunciación comprende el enunciador/enunciatario como los dos polos implícitos que configuran el enunciado.

(3) Lo primero que se cuestiona es la existencia de una literatura dicha infantil. Los que la afirman, lo hacen con argumentos extraliterarios: Enzo Petrini. Estudio de la literatura juvenil, Madrid: Edc. Rialp. S., 1958, pág. 58; Carmen Bravo, Historia de la Literatura infantil española. Madrid: Revista de Occidente, 1959, pág. 11. Luego se plantea si la literatura infantil es la escrita por o para los niños. La balanza crítica se inclina por la segunda posibilidad, aunque no se niega importancia a la primera. Consúltese: Jesualdo. La literatura infantil: ensayo sobre ética, estética y psicopedagogía. Buenos Aires, Editorial Losada, 1963, pág. 51.

(4) E. Petrini. Op. Cit., pág. 200.

(5) Las categorías estética y ética siempre están presentes en la crítica. Un "buen" libro de literatura infantil es aquel que posee ambos valores. De hecho, al verosímil crítico -organizado a partir de dicotomía- de la crítica costarricense (referencialidad/no referencialidad, naturalidad/artificiosidad, presencia del autor/ausencia del autor) hubo que agregarle dos más: valor didáctico/no didáctico y creación/no creación. Véase Patricia Araujo y otros. Rasgos comunes... Op. Cit., págs. 28-36.
(6) Vladimir Propp Las transformaciones del cuento maravilloso (Buenos Aires: Rodolfo Alonso Editor, 1972) sirve de base a una serie de estudios que se van a ocupar del cuento folklórico, quizás el más importante: $\mathrm{A}$. Greimas. Du sens París: Edit. du Seuil, 1970.

(7) Para analizar este aspecto resulta fundamental el artículo de C. Bremond: "La logique des possibles narratifs" En: L'analyse structurale du récit. París: Edit. du Seuil, 1981, págs. 66-82.

(8) E. Petrini establece estas características como los "motivos guías" de la literatura de ficción originaria; op. cit., págs. 40-41.

(9) Bruno Bettelheim. Psicoanálisis de los cuentos de hadas. Madrid: Editorial Crítica, 1979.

(10) Para Tzvetan Todorov, el cuento de hadas es "una de las variedades de lo maravilloso y los acontecimientos sobrenaturales no provocan en él sorpresa alguna..." "Lo que distingue el cuento de hadas es una cierta escritura". Introducción a la Literatura fantástica Argentina: Edit. Tiempo Contemporáneo, 1974, pág. 68.

(11) Alga Marina Elizagaray. En torno a la literatura infantil. La Habana: Unión de escritores y artistas de Cuba, 1975, pág. 25.

(12) J. Gutiérrez Mangel. "Cocorí es mi hijo menor". En: Universidad, 8 de julio de 1974.

(13) Carlos Cortés "Más sabe el diablo por viejo...". En: Universidad (Suplemento Forja, 8-14 de enero de 1982, págs. 4-5.

(14) Ibidem y "Cocorí". En: La Nación, 24 de junio de 1980, pág. 3 C.

(15) A. Greimas y J. Courtés en Semiótique: dictionnaire raisonné de la théorie du langage (París: Hachette Université, 1979), distingue la dimensión del conocimiento y la dimensión pragmática del discurso, lo mismo 
que, los sujetos pragmáticos de los sujetos cognitivos. La dimensión cognitiva siempre conlleva la pragmática y se desarrolla paralelamente con el aumento del saber atribuido a los sujetos instalados en el discurso, págs. 40 , 288 y 370.

(16) E. Margery P. en "Alcances en torno a la problemática del narrador". (Revista de Filología, Lingüística y Literatura. Universidad de Costa Rica, tomo 1, No. 2, mayo de 1975) acepta las categorías "externa" e "interna" para el destinatario, la primera si coresponde a una entidad conocida del hablante básico y la segunda, si se trata de un lector indeterminado. Pág. 58. G. Genette, en Figures /I/ (París: Edit. du Seuil, 1972) distingue también entre un narratario extradiegético, es decir fuera de la Historia y uno intradiegético o incluido dentro de ella; pág. 265.

(17) G. Genette, Op. Cit., págs. 238 y siguientes.

(18) La edición de Cocorí utilizada en el trabajo es la de 1957, publicada en Santiago de Chile, por la Editorial Nascimento. Para simplificar las citas, al lado de cada ejemplo aparece la página correspondiente.

(19) En la sociedad del intercambio, los textos se presentan como productos listos para el con- sumo de donde se borran todas las huellas de la producción. Julia Kristeva a través de sus primeras obras (Texte du roman, Seméiotike, La traversée du signe), define los textos como prácticas significantes y distingue tres tipos: las simbólicas, las sígnicas y las paragramáticas. Entre ellas, las paragramáticas pretenden mostrar el trabajo de producción, las otras lo ocultan.

(20) G. Genette, Op. Cit. pág. 262.

(21) Roman Jakobson. Essais de linguistique génerale. París: Edt. de Minuit, 1970, págs. 213-220.

(22) G. Genette, Ibidem.

(23) P. Araujo y otros. Rasgos..., Op. Cit., pág. 514.

(24) Tzvetan Todorov, en "Los registros del habla", se refiere a la naturaleza "concreta" o "abstracta" del discurso; en un lado coloca el ser singular, material; y "en el otro las reflexiones 'generales' que anuncian una verdad fuera de toda referencia espacial y temporal. Entre ambos extremos se sitúa una infinidad de casos intermedios". Todorov, Tzvetan ¿Qué es el estructuralismo? Poética. Buenos Aires: Editorial Losada S. A.; 1975, pág. 46. 